\title{
Intraspecific traits change biodiversity effects on ecosystem functioning under metal stress
}

\author{
Isabel Fernandes · Cláudia Pascoal • \\ Fernanda Cássio
}

Received: 14 March 2010/Accepted: 31 January 2011/Published online: 22 February 2011

(c) Springer-Verlag 2011

\begin{abstract}
Studies investigating the impacts of biodiversity loss on ecosystem processes have often reached different conclusions, probably because insufficient attention has been paid to some aspects including (1) which biodiversity measure (e.g., species number, species identity or trait) better explains ecosystem functioning, (2) the mechanisms underpinning biodiversity effects, and (3) how can environmental context modulates biodiversity effects. Here, we investigated how species number (one to three species) and traits of aquatic fungal decomposers (by replacement of a functional type from an unpolluted site by another from a metal-polluted site) affect fungal production (biomass acumulation) and plant litter decomposition in the presence and absence of metal stress. To examine the putative mechanisms that explain biodiversity effects, we determined the contribution of each fungal species to the total biomass produced in multicultures by real-time PCR. In the absence of metal, positive diversity effects were observed for fungal production and leaf decomposition as a result of species complementarity. Metal stress decreased diversity effects on leaf decomposition in assemblages containing the functional type from the unpolluted site, probably due to competitive interactions between fungi. However, dominance effect maintained positive diversity
\end{abstract}

Communicated by Robert Hall.

Electronic supplementary material The online version of this article (doi:10.1007/s00442-011-1930-3) contains supplementary material, which is available to authorized users.

I. Fernandes · C. Pascoal · F. Cássio $(\bowtie)$

Centre of Molecular and Environmental Biology (CBMA),

Department of Biology, University of Minho, Campus de

Gualtar, 4710-057 Braga, Portugal

e-mail: fcassio@bio.uminho.pt effects under metal stress in assemblages containing the functional type from the metal-polluted site. These findings emphasize the importance of intraspecific diversity in modulating diversity effects under metal stress, providing evidence that trait-based diversity measures should be incorporated when examining biodiversity effects.

Keywords Intraspecific diversity - Ecosystem processes . Leaf decomposition · Aquatic fungi · Freshwaters

\section{Introduction}

Since the early 1990s, a large number of studies in ecology have focused on the question of how biodiversity matters for ecosystem functioning. Most results point to positive effects of species richness on ecosystem processes (Hooper et al. 2005; Gamfeldt and Hillebrand 2008; Pascoal and Cássio 2008; Reiss et al. 2009) and conclusions have been supported by meta-analyses with different trophic groups (producers, herbivores, detritivores and predators) from aquatic and terrestrial ecosystems (Balvanera et al. 2006; Cardinale et al. 2006). However, some questions that still need to be further addressed to better understand how biodiversity modulates ecosystem functioning are (1) which diversity measure (e.g., gene, trait or species) better predicts ecosystem functioning (Hughes and Stachowicz 2004; Reusch et al. 2005; Gamfeldt and Källström 2007), (2) which are the mechanisms behind biodiversity effects (Loreau and Hector 2001; Fox 2005; Hector et al. 2009), and (3) how environmental change modulates the effects of diversity on ecosystem processes.

It has been assumed that positive effects of diversity on ecosystem functioning can be partitioned into two components: complementarity effects due to facilitative 
interactions between species or resource partitioning, and selection effects due to the greater probability that a diverse community includes dominant species with particular traits (Loreau and Hector 2001). However, species with particular traits can perform better than expected in multicultures either due to competitive replacement of other species or due to the expression of their traits without negative impacts to others (Fox 2005; Hector et al. 2009). Therefore, a tripartite model, including the "so-called" (1) dominance effect, when species with particular traits dominate at expense of others, (2) trait-dependent complementarity, when species with particular traits dominate in multicultures but not at the expense of others, and (3) trait-independent complementarity, when species performances in multicultures increase independently of their traits and not at the expense of others (equivalent to the complementarity defined by Loreau and Hector 2001), would best describe the mechanisms underpinning net biodiversity effects (Fox 2005).

Over the last few years, the use of microbial assemblages as model systems in ecology has been increasing mainly because microorganisms are ubiquitous, have short generation times, and are easy to manipulate under controlled conditions (Jessup et al. 2004). Moreover, they are key players in several environmental services, like nutrient recycling, water purification and carbon sequestration (Ducklow 2008); so, it becomes essential to understand how changes in microbial diversity can influence the underlying ecosystem processes (Reiss et al. 2010).

In freshwaters, microorganisms together with invertebrates are the biotic drivers of plant litter decomposition. Freshwater microbes are sensitive to environmental changes, and shifts in microbial assemblages on plant litter have been associated with alterations in the available resources (leaf litter quality, Marks et al. 2009; Kominoski et al. 2009; inorganic nutrients, Ferreira et al. 2006), temperature (Fernandes et al. 2009b) or water quality (Sridhar et al. 2001; Duarte et al. 2009). A polyphyletic group of fungi known as aquatic hyphomycetes are the major microbial decomposers of plant litter (Pascoal and Cássio 2004; Das et al. 2007); they produce a vast array of hydrolytic enzymes able to degrade plant cell-wall polysaccharides, and they act as intermediaries between plant litter and higher trophic levels (Bärlocher 2005).

The effects of aquatic fungal diversity on leaf litter decomposition have been described as positive or neutral, depending on the environmental context. A decrease in diversity of aquatic fungi in streams affected by changes in riparian vegetation (Bärlocher and Graça 2002; Lecerf et al. 2005) or moderate pollution (Raviraja et al. 1998; Pascoal et al. 2005a) was not accompanied by a reduction in leaf decomposition rates (Raviraja et al. 1998; Bärlocher and Graça 2002; Lecerf et al. 2005, Pascoal et al. 2005a). However, in severely metal-polluted streams with impoverished aquatic hyphomycete assemblages (Sridhar et al. 2000), leaf decomposition proceeded at low rates (Sridhar et al. 2001). A positive relationship between aquatic fungal diversity and leaf decomposition has been observed in manipulative experiments (Bärlocher and Corkum 2003; Treton et al. 2004; Duarte et al. 2006; Raviraja et al. 2006; but see Dang et al. 2005). However, the positive diversity effects on leaf decomposition were less pronounced under metal stress (Pascoal et al. 2010), suggesting that traits that determine how a particular species affects ecosystem processes can differ from traits that determine how that species responds to an environmental stressor. Moreover, it is expected that performances might be determined by individual traits, which can vary within a species. Hence, a trait-based biodiversity measure should better reflect the potential for assemblages'performance than does species richness per se (Reiss et al. 2009).

Most studies examining the relationships between microbial diversity and ecological processes have been limited by difficulties in tracking individual species performances within assemblages (Bärlocher and Corkum 2003; Duarte et al. 2006). DNA-based approaches have the potential to overcome this problem (Pascoal et al. 2010), but they rely on polymerase chain reaction (PCR) and bias such as preferential amplification can occur (Kanagawa 2003). Real-time PCR is currently the most promising technique to circumvent this limitation because it can accurately quantify the amount of DNA in a sample (Kubista et al. 2006). Therefore, real-time PCR may be useful to determine the contribution of each species to the total assemblage performance (e.g., Kennedy et al. 2007) and to discriminate the mechanisms behind microbial diversity effects on ecosystem functioning.

In this study, we manipulated a pool of three widespread aquatic hyphomycete species including two functional types of a highly productive species, one from an unpolluted site and another from a metal-polluted site, to clarify (1) if lower richness of aquatic hyphomycetes reduces leaf decomposition, (2) if diversity effects are modulated by intraspecific traits, (3) the mechanisms behind diversity effects (complementarity and dominance), and (4) if diversity effects change under metal stress. We hypothesized that under metal stress intraspecific traits would change biodiversity effects on ecosystem functioning due to the expression of unique traits to cope with metal stress. If so, genetic diversity might be more important than species richness to maintain ecosystem functions under changing environmental conditions. The measured endpoints were leaf mass loss, and fungal production as ergosterol accumulation and DNA content (estimated by real-time PCR). 


\section{Materials and methods}

Fungal species

We selected three widespread aquatic hyphomycete species in Portugal: Flagellospora curta J. Webster (UMB-39.01; FC39), Tricladium splendens Ingold (UMB-100.01; TS100) and two isolates of Articulospora tetracladia Ingold (UMB-61.01, AT61; and UMB-72.01, AT72). The functional type $A T 72$ was isolated from foam collected in the Maceira stream, an unpolluted stream at the PenedaGerês National Park (northwest Portugal). The other fungi were isolated from decomposing leaves collected in the Este River near the city of Braga (northwest Portugal), at a site impacted by metals including cadmium (Cd) (Soares et al. 1999; Pascoal et al. 2005a).

Pure cultures of aquatic hyphomycetes on $2 \%$ malt extract agar were prepared for microcosm inoculation.

\section{Microcosm setup}

In October 2007, leaves of Alnus glutinosa (L.) Gaertn. (alder) were collected immediately before abscission and dried at room temperature. The leaves were leached in deionised water for 2 days, and cut into 12-mm-diameter disks. Sets of 25 disks were placed in 150-mL Erlenmeyer flasks and autoclaved $\left(120^{\circ} \mathrm{C}, 20 \mathrm{~min}\right)$. To each flask, $70 \mathrm{~mL}$ of filtered (filter paper; Macherey-Nagel, Düren, Germany) and autoclaved stream water was added aseptically. Physical and chemical analysis of the stream water indicated circumneutral $\mathrm{pH}$ (6.34), low conductivity (40 $\mu \mathrm{S} \mathrm{cm}^{-1}$, Multiline F/set 3 no. 400327; WTW, Weilheim, Germany), moderate concentrations of nitrate (0.3 $\mathrm{mg} \mathrm{L}^{-1} \mathrm{NO}_{3}{ }^{-}-\mathrm{N}, \mathrm{HACH}$ kit, program 351) and phosphate $\left(0.05 \mathrm{mg} \mathrm{L}^{-1} \mathrm{PO}_{4}{ }^{3-}-\mathrm{P}, \mathrm{HACH}\right.$ kit, program 490), and low concentration of nitrite $\left(0.002 \mathrm{mg} \mathrm{L}^{-1}\right.$ $\mathrm{NO}_{2}{ }^{-}-\mathrm{N}$, $\mathrm{HACH}$ kit, program 371) and ammonium $\left(<0.01 \mathrm{mg} \mathrm{L}^{-1} \mathrm{NH}_{4}{ }^{+}-\mathrm{N}, \mathrm{HACH}\right.$ kit, program 385$)$.

Sterilized (Filtropur S, $0.2 \mu \mathrm{m}$; SARSTEDT, Rio de Mouro, Portugal) stock solution of $\mathrm{Cd}$ was added to 44 microcosms to a final concentration of $1.5 \mathrm{mg} \mathrm{L}^{-1} \mathrm{Cd}$ (chloride salt; Sigma). This Cd concentration led to a $50 \%$ inhibition of biomass produced by the most sensitive species among five aquatic hyphomycetes (Azevedo and Cássio 2010), collected from the same contaminated site as most fungi used in this study. In metal-polluted streams, Cd in the water column can reach $3.2 \mathrm{mg} \mathrm{L}^{-1}$ (Sridhar et al. 2000), making the Cd concentration used in our study environmentally relevant. An additional 44 microcosms without added $\mathrm{Cd}$ were used as controls.

Microcosms were inoculated with agar plugs, collected from the edge of 19-day-old colonies of the four fungi, in monoculture or in all possible combinations (4 replicates per treatment), never mixing the strains of the same species. Inoculation of single species microcosms was done with a 6-mm-diameter plug. For multiple-species microcosms, the total inoculum size was maintained and divided equally among species.

The microcosms were incubated for 35 days on a shaker (120 rpm; Certomat BS 3, Melsungen, Germany) at $16^{\circ} \mathrm{C}$, under artificial light, and stream water was changed every 5 days. At the end of the experiment, leaf disks were used to determine leaf mass loss, fungal biomass and fungal DNA content.

\section{Fungal biomass}

Fungal biomass on leaves was estimated from ergosterol concentration according to Gessner (2005). Briefly, lipids were extracted from sets of 6 freeze-dried leaf disks by heating $\left(80^{\circ} \mathrm{C}, 30 \mathrm{~min}\right)$ in $8 \mathrm{~g} \mathrm{~L}^{-1}$ of $\mathrm{KOH}-$ methanol. Ergosterol was purified by solid-phase extraction and quantified at $282 \mathrm{~nm}$ by high performance liquid chromatography (HPLC; Beckmann Gold System, Brea, CA, USA) on a LiChrospher RP18 column, using methanol as the mobile phase $\left(33^{\circ} \mathrm{C}, 1.4 \mathrm{~mL} \mathrm{~min}^{-1}\right)$.

To convert ergosterol concentration into fungal biomass, specific conversion factors for each fungal isolate were determined by measuring ergosterol concentration in fungal mycelia along the exponential growth phase in liquid medium $\left(1 \%\right.$ malt extract, $\left.140 \mathrm{rpm}, 16^{\circ} \mathrm{C}\right)$. The ergosterol was extracted from ca. $5 \mathrm{mg}$ of freeze-dried mycelia and quantified as above. The conversion factors were $3.1 \pm 0.3$, $3.4 \pm 0.3,3.7 \pm 0.4$ and $10.3 \pm 0.2 \mu \mathrm{g}$ ergosterol $\mathrm{mg}^{-1}$ fungal dry mass for TS100, AT72, AT61 and FC39, respectively (values are mean \pm SEM, 5 sampling times, 3 replicates, $n=15$ ). Previous experiments with $A$. tetracladia (AT61) and F. curta (FC39) showed that Cd exposure did not significantly affect ergosterol concentration (unpublished results).

Fungal DNA quantification by real-time polymerase chain reaction

Real-time PCR uses fluorescent probes to monitor the DNA amplification allowing us to accurately quantify the amount of initial DNA template of each fungus in mixtures. To establish standard curves relating DNA amounts and $\mathrm{Ct}$ values (i.e., the number of cycles at which the fluorescence value exceeds the background fluorescence and crosses the threshold, Kubista et al. 2006) for each fungal isolate, DNA from pure cultures (ca. $5 \mathrm{mg}$ of fungal mycelia grown in $1 \%$ malt extract during 20 days) was extracted using the UltraClean Soil DNA kit (MoBio Laboratories, Solana Beach, CA, USA). The ITS2 region of each fungal rDNA was amplified with the primer pair ITS3 and ITS4 (White 
et al. 1990; Duarte et al. 2009). PCR products were purified with GenElute ${ }^{\mathrm{TM}}$ PCR Clean-Up kit (Sigma-Aldrich, Sintra, Portugal), according to the manufacturer instructions, and sequenced at the Centre of Molecular and Environmental Biology, University of Minho, Portugal (ABI PRISM $^{\circledR} 310$ Genetic Analyzer; Applied Biosystems, Foster City, CA, USA). DNA sequences were submitted to GenBank (http://www.ncbi.nlm.nih.gov/Genbank/) with the accession numbers: AT61, GU938614; AT72, GU938615; FC39, GU938616; and TS100, GU938617. Species-specific primer pairs were designed using the Primer Express 2.0 software (Applied Biosystems) (Online Resource Table S1).

For real-time PCR reactions, we mixed $1 \mu \mathrm{L}$ of DNA sample, $5 \mu \mathrm{L}$ of $2 \times$ LightCycler $^{\circledR} 480$ SYBR Green I Master mix (Roche), $250 \mathrm{nM}$ of each species-specific primer and nuclease-free water in a final volume of $10 \mu \mathrm{L}$. DNA amplification started with initial denaturation at $95^{\circ} \mathrm{C}$ for $10 \mathrm{~min}$, followed by 45 cycles of denaturation at $95^{\circ} \mathrm{C}$ for $10 \mathrm{~s}$, primer hybridization at $60^{\circ} \mathrm{C}$ during $20 \mathrm{~s}$ and extension at $72^{\circ} \mathrm{C}$ during $15 \mathrm{~s}$.

DNA concentration was measured with a NanoDrop ${ }^{\circledR}$ ND-1000 Spectrophotometer (Thermo Scientific). DNA samples from each fungus were diluted at tenfold intervals from $10 \mathrm{ng}$ to $1 \mathrm{pg}$, and duplicates of all dilutions were done to establish linear regressions between DNA amounts and $\mathrm{Ct}$ values. The coefficient of determination of all fits was $>0.99$ (Online Resource Table S2). Real-time PCR efficiencies ranged from 1.76 to 1.98 for AT61 and TS100, respectively (Online Resource Table S2). Negative controls were performed by testing all specific primers against all isolates, and no fluorescence of non-target template was observed in single-species treatments (not shown).

To assess the DNA content of each fungal species in microcosms, real-time PCR of DNA extracted from four leaf disks ( 1 disk from each replicate, pooled from 4 replicates) was done as described above. In all samples, no fluorescence of non-target template was observed (negative controls). Real-time PCR was done in a LightCycler ${ }^{\circledR} 480$ System (Roche) at the Unidad de Genómica Toñi Martín Gallardo, Parque Científico de Madrid, Spain.

Leaf dry mass

Sets of 18 leaf disks from each replicate microcosm were freeze-dried to constant mass $(72 \pm 24 \mathrm{~h})$ and weighed $( \pm 0.001 \mathrm{~g})$. Sets of leaf disks before fungal inoculation were used to estimate initial leaf dry mass.

\section{Data analyses}

Three-way nested ANOVAs were used to test the effects of $\mathrm{Cd}$, species number and species identity (nested in species number) as fixed factors on leaf mass loss and fungal biomass (Duarte et al. 2006; Pascoal et al. 2010). Differences between treatments were analysed by a Tukey's posttest (Zar 1996).

Linear regressions between log DNA amount and $\mathrm{Ct}$ values were done (Online Resource Table S2), with Prism 4.0 for Windows (GraphPad, San Diego, CA, USA). The Ct values of each fungal isolate obtained by real-time PCR were converted to DNA and were used to calculate the percentage of each isolate in multicultures as follows:

$P_{i}=\frac{D N A_{i}}{\sum_{i=1}^{N} D N A_{i}}$,

where $P_{i}$ is the percentage of species $i$ in multicultures, $N$ is the number of species and $\mathrm{DNA}_{i}$ is the DNA amount of species $i$ assessed by real-time PCR. Ergosterol was converted to fungal biomass as:

$B_{t}=\frac{E_{t}}{\sum_{i=1}^{N}\left(P_{i} \times F_{i}\right)}$,

where $B_{t}$ is the total fungal biomass, $E_{t}$ is the total ergosterol content, $P_{i}$ is the percentage of species $i$ in multiculture containing $N$ species, and $F_{i}$ is the ergosterol-tobiomass conversion factor of species $i$. Because leaves were the only carbon and energy source available for fungi, species contribution to leaf mass loss was assumed to be proportional to the biomass produced by individual fungal species in mixtures.

To discriminate the mechanisms behind net biodiversity effects, the tripartite partition model (Fox 2005) was applied to fungal biomass and leaf mass loss, as follows:

$$
\begin{aligned}
\Delta Y= & N E(M) E(\Delta R Y)+N \operatorname{cov}\left(M, \frac{R Y_{O}}{R Y T_{O}}-R Y_{E}\right) \\
& +N \operatorname{cov}\left(M, R Y_{O}-\frac{R Y_{O}}{R Y T_{O}}\right)
\end{aligned}
$$

where the first term is the contribution of trait-independent complementarity, the second term is the contribution of dominance, and the final term is the contribution of traitdependent complementarity to the net biodiversity effects $(\Delta Y)$. In the equation, $N$ is the number of species in the mixture, $E$ is unweighted arithmetic mean across all $N$ species, $M$ is the monoculture yield of each species, and $\Delta R Y$ is the difference between the observed $\left(R Y_{O}\right)$ and expected $\left(R Y_{E}\right)$ relative yields of species in the mixture. $R Y_{O}$ of a species is its yield in mixture divided by its yield in monoculture. $R Y_{E}$ of a species is the initial proportion of a species in the mixture. $R Y T_{O}$ is the sum of $R Y_{O}$ for all species in the mixture. Net biodiversity effects were square-root transformed with original signs preserved to 
improve normality (Loreau and Hector 2001; Fox 2005), and tested against the null hypothesis that the values equalled 0 ( $t$ test) (Pascoal et al. 2010). The statistical analyses were performed with Statistica 6.0 for Windows (Statsoft, Tulsa, OK, USA).

\section{Results}

Leaf decomposition and fungal biomass on leaves

Cadmium affected leaf decomposition by fungi differently depending on the functional type present in the assemblage (Fig. 1a, b). In microcosms without $\mathrm{Cd}$, the average leaf mass loss varied between $17 \%$ in the monoculture of Flagellospora curta (FC39) and $34 \%$ in multicultures with three species containing Articulospora tetracladia isolated from the unpolluted site (AT72) (Fig. 1a). Cadmium, species identity, and interaction between $\mathrm{Cd}$ and species identity significantly affected leaf mass loss (three-way nested ANOVA, $P<0.05$; Table 1). Leaf mass loss decreased after $\mathrm{Cd}$ addition in multicultures with three species containing AT72 (Tukey's test, $P<0.05$; Fig. 1b), but not in mixtures containing the strain of A. tetracladia isolated at the polluted site (AT61) (Tukey's test, $P>0.05)$.
Fungal biomass increased with increasing species number $\left(\mathrm{y}=22.2 \mathrm{x}+5.2, r^{2}=0.42 ; P<0.0001\right)$, except in the presence of $\mathrm{Cd}$ (Fig. 1c, d). Without Cd addition, fungal biomass on leaves varied between $5 \mathrm{mg} \mathrm{g}^{-1}$ leaf dry mass in monoculture of $F C 39$ and $95 \mathrm{mg} \mathrm{g}^{-1}$ leaf dry mass in the multicultures of three species containing AT61 (Fig. 1c). Species identity, species number, and interactions between $\mathrm{Cd}$ and the other factors significantly affected fungal biomass (three-way nested ANOVA, $P<0.05$; Table 1). Fungal biomass increased with $\mathrm{Cd}$ addition in monoculture containing AT61, and decreased in (1) duoculture containing AT72 and FC39 and (2) multiculture of three species containing AT72 or AT61 (Tukey's test, $P<0.05$ for all cases; Fig. 1d). The highest fungal biomasses corresponded to treatments with the strain AT61.

Fungal species dominance on leaves

The pattern of fungal species dominance on leaves changed in the presence of $\mathrm{Cd}$ (Fig. 2). Without Cd addition, $A$. tetracladia showed a clear dominance $(>85 \%$ for both AT72 and AT61) in all multicultures containing this species (Fig. 2a-d, f, g). Cadmium exposure decreased at least $60 \%$ the contribution of $A T 72$ in multicultures with either two or three species (Fig. 2a, c, f), while it increased the
Fig. 1 a, b Leaf mass loss and c, $\mathbf{d}$ fungal biomass on decomposing alder leaves after 35 days in microcosms, a, $\mathbf{c}$ non-exposed or $\mathbf{b}, \mathbf{d}$ exposed to $1.5 \mathrm{mg} \mathrm{L}^{-1}$ cadmium (mean + SEM, $n=4)$. Horizontal lines indicate average values in treatments containing one, two or three fungal species. Articulospora tetracladia UMB-72.01 (AT72), A. tetracladia UMB-61.01 (AT61), Flagellospora curta UMB-39.01 (FC39), and Tricladium splendens UMB100.01 (TS100). Ergosterol concentration was converted into fungal biomass using specific ergosterol-to-biomass conversion factors for each isolate and taking into account the percentage contribution of each species in mixtures, assessed by real-time PCR (see "Materials and methods")
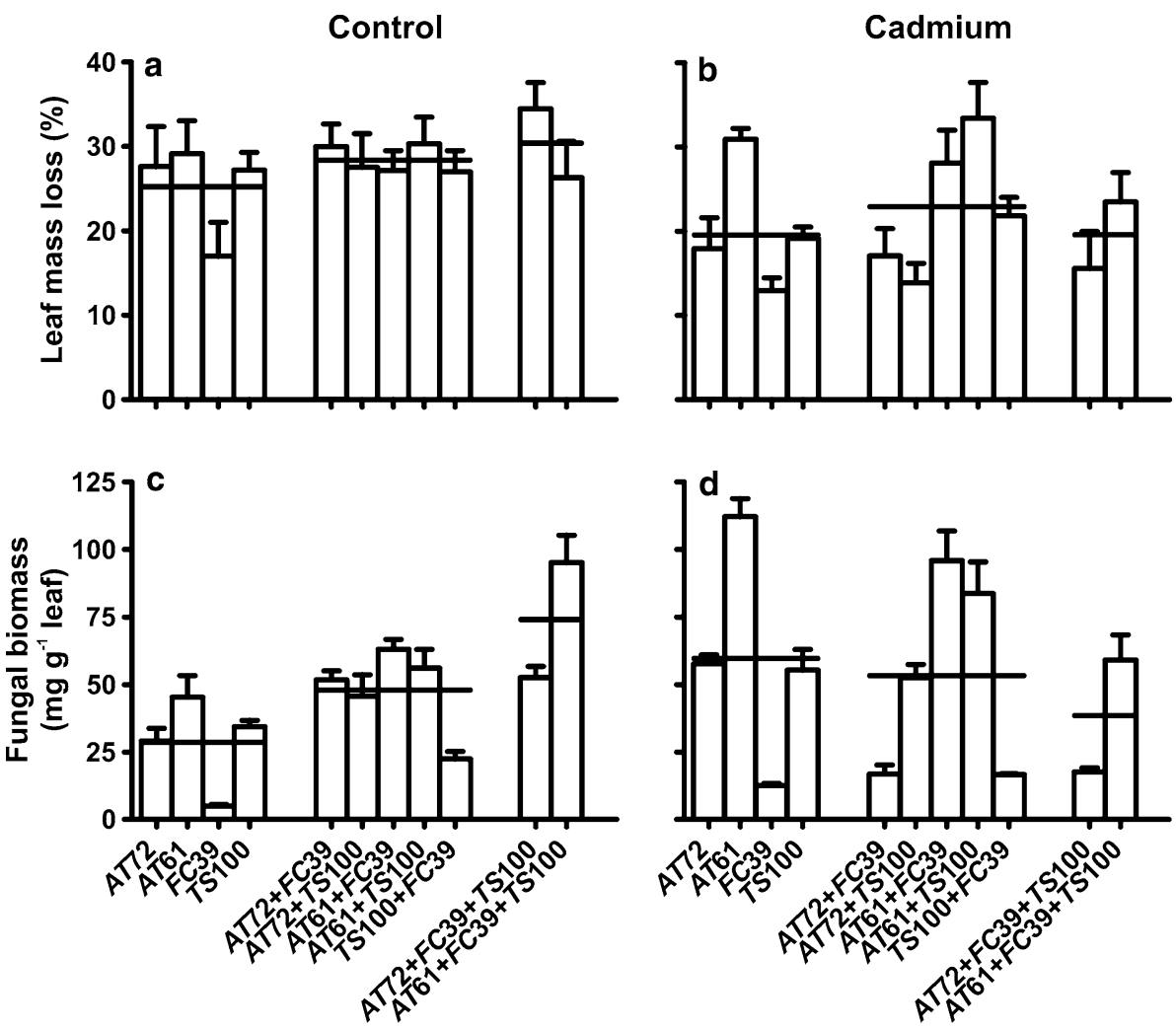

Fungal species treatment 
Table 1 ANOVAs of the effects of cadmium (Cd), species number and species identity on leaf mass loss and fungal biomass

\begin{tabular}{|c|c|c|c|c|c|c|}
\hline & Effect & $d f$ & SS & MS & $F$ & $P$ \\
\hline \multirow[t]{6}{*}{ Leaf mass loss } & Identity (species number) & 8 & $1,428.2$ & 178.5 & 4.1 & $<0.01$ \\
\hline & Species number & 2 & 149.3 & 74.6 & 1.7 & 0.19 \\
\hline & $\mathrm{Cd}$ & 1 & 951.1 & 951.1 & 22.0 & $<0.01$ \\
\hline & Identity (species number) $\times \mathrm{Cd}$ & 8 & 874.1 & 109.3 & 2.5 & 0.02 \\
\hline & Species number $\times \mathrm{Cd}$ & 2 & 101.8 & 50.9 & 1.2 & 0.31 \\
\hline & Error & 65 & $2,807.7$ & 43.2 & & \\
\hline \multirow[t]{6}{*}{ Fungal biomass } & Identity (species number) & 8 & $46,165.4$ & $5,770.7$ & 37.5 & $<0.01$ \\
\hline & Species number & 2 & $1,714.4$ & 857.2 & 5.6 & $<0.01$ \\
\hline & $\mathrm{Cd}$ & 1 & 120.2 & 120.2 & 0.8 & 0.38 \\
\hline & Identity (species number) $\times \mathrm{Cd}$ & 8 & $9,878.9$ & $1,234.9$ & 8.0 & $<0.01$ \\
\hline & Species number $\times \mathrm{Cd}$ & 2 & $11,883.4$ & $5,941.7$ & 38.6 & $<0.01$ \\
\hline & Error & 66 & $10,162.0$ & 154.0 & & \\
\hline
\end{tabular}

contribution of $F C 39$ to more than $70 \%$ (Fig. 2a, e, f). The strain AT61 maintained its contribution above $90 \%$ in multicultures exposed or not to $\mathrm{Cd}$ (Fig. $2 \mathrm{~b}, \mathrm{~d}, \mathrm{~g}$ ). In the absence of $\mathrm{Cd}, T S 100$ and FC39 had similar contributions to the total fungal DNA in duoculture, but the exposure to Cd increased the contribution of FC39 to more than $90 \%$ (Fig. 2e).

Partitioning biodiversity effects on leaf decomposition and fungal biomass

Net biodiversity effects and the underlying mechanisms changed under $\mathrm{Cd}$ exposure (Fig. 3). Without $\mathrm{Cd}$ addition, net biodiversity effects on leaf mass loss were positive for assemblages containing A. tetracladia from the unpolluted (AT72) or the polluted site (AT61) ( $t$ tests, $P<0.05$; Fig. 3a). These effects were mainly a result of trait-independent complementarity for assemblages with AT72 and were a result of both trait-independent complementarity and dominance effects for assemblages with AT61. The positive net biodiversity effects due to trait-independent complementarity and dominance were kept under $\mathrm{Cd}$ exposure in assemblages with AT61 ( $t$ test, $P=0.02$ ), but no significant net biodiversity effects were found in assemblages with $A T 72$ ( $t$ test, $P=0.79$; Fig. 3b).

Net biodiversity effects on fungal biomass were also positive for assemblages non-exposed to $\mathrm{Cd}$ containing $A T 72$ or AT61 ( $t$ tests, $P<0.05$ ) due to trait-independent complementarity between species (Fig. 3c). The exposure to Cd led to negative net biodiversity effects for assemblages containing AT72 ( $t$ test, $P=0.01$ ) mainly as a result of dominance effects, and no significant net biodiversity effects were found in assemblages containing AT61 ( $t$ test, $P=0.95$; Fig. 3d).

\section{Discussion}

Our study clearly shows that intraspecifc traits altered biodiversity effects under metal stress: the positive effects of fungal diversity on leaf decomposition and fungal biomass production were kept under $\mathrm{Cd}$ stress only when the assemblage had a Cd-resistant functional type. Positive relationships between aquatic hyphomycete diversity and leaf decomposition (Bärlocher and Corkum 2003; Treton et al. 2004; Duarte et al. 2006; Raviraja et al. 2006; Pascoal et al. 2010) or fungal biomass production (Duarte et al. 2006; Raviraja et al. 2006; Pascoal et al. 2010) have been reported, but these relationships are likely to change under stress (Pascoal et al. 2010).

In this study, fungal diversity effects appeared to be stronger on fungal biomass production than on leaf decomposition as found by others (Duarte et al. 2006; Pascoal et al. 2010). If increased diversity had favored higher growth efficiencies [i.e., production/(production + respiration)], this mechanism would explain the less pronounced diversity effects on leaf decomposition. However, $\mathrm{Cd}$ appeared to decrease growth efficiency of the assemblages because fungal biomass decreased with the increase of species number, particularly in multicultures with three species. It is conceivable that growth efficiency and resource depletion may vary in different assemblages or under different environmental conditions, supporting the need of considering several response variables when examining biodiversity effects (Reiss et al. 2009).

We used real-time PCR to track each species within fungal assemblages; this allowed us to discriminate the contribution of trait-independent complementarity, traitdependent complementarity and dominance to net biodiversity effects (Fox 2005) in microbial assemblages. In the absence of $\mathrm{Cd}$, trait-independent complementarity 

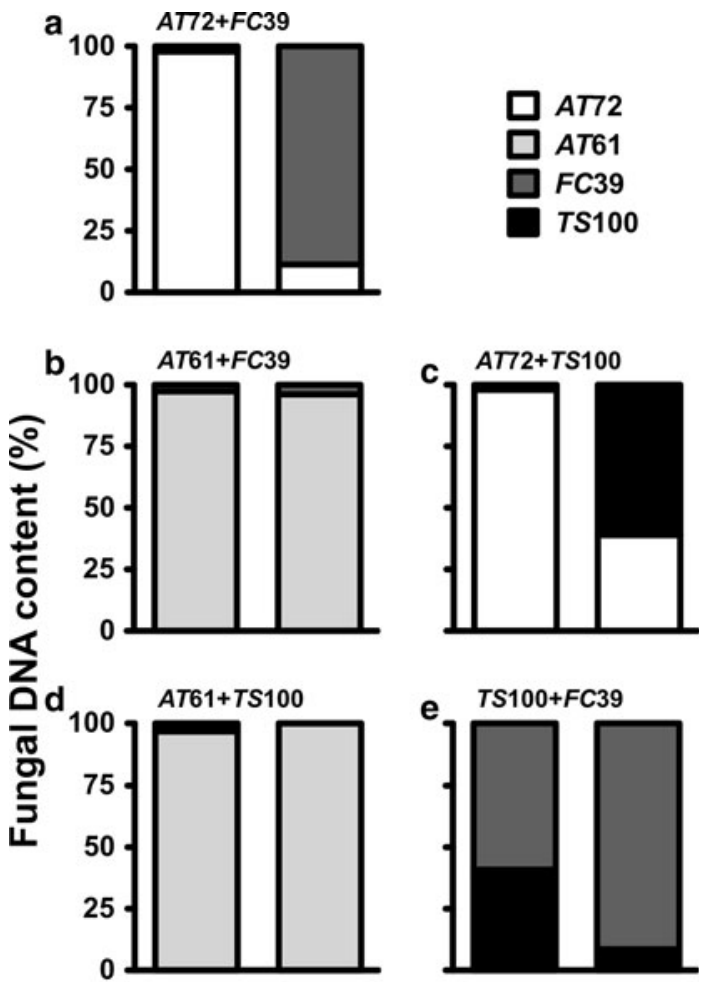

$T S 100+F C 39$
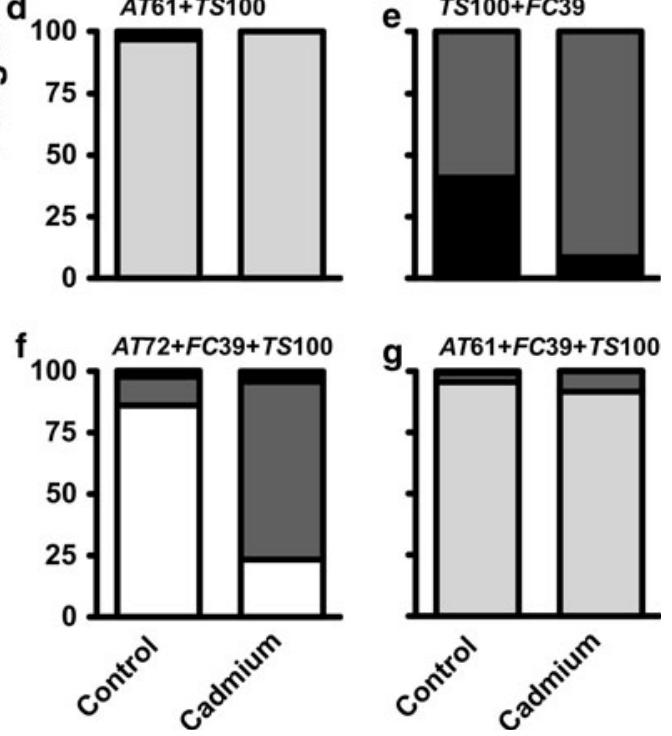

Fig. 2 Percentage contribution of each fungal isolate to the total DNA content in multicultures with $\mathbf{a}-\mathbf{e}$ two and $\mathbf{f}, \mathbf{g}$ three fungal species in control and cadmium-exposed microcosms, assessed by real-time PCR. At each treatment, DNA was extracted from four pooled replicates. Fungal species abbreviations as in Fig. 1

explained most of the positive net biodiversity effects, suggesting that increased leaf mass loss and fungal production resulted from the better performance of all fungi in mixtures rather than the supremacy of a dominant species. This finding agrees with the evidence that aquatic hyphomycete species preferentially colonize different patches of leaves (Bermingham et al. 1996). Moreover, different species have variable patterns of exoenzymes active against a range of plant polymers (Suberkropp et al. 1983), probably leading to a better resource use in multicultures.

Net biodiversity effects changed under $\mathrm{Cd}$ exposure with shifts from trait-independent complementarity to dominance effects. The exposure to $\mathrm{Cd}$ led to a decrease of net biodiversity effects on leaf decomposition (no

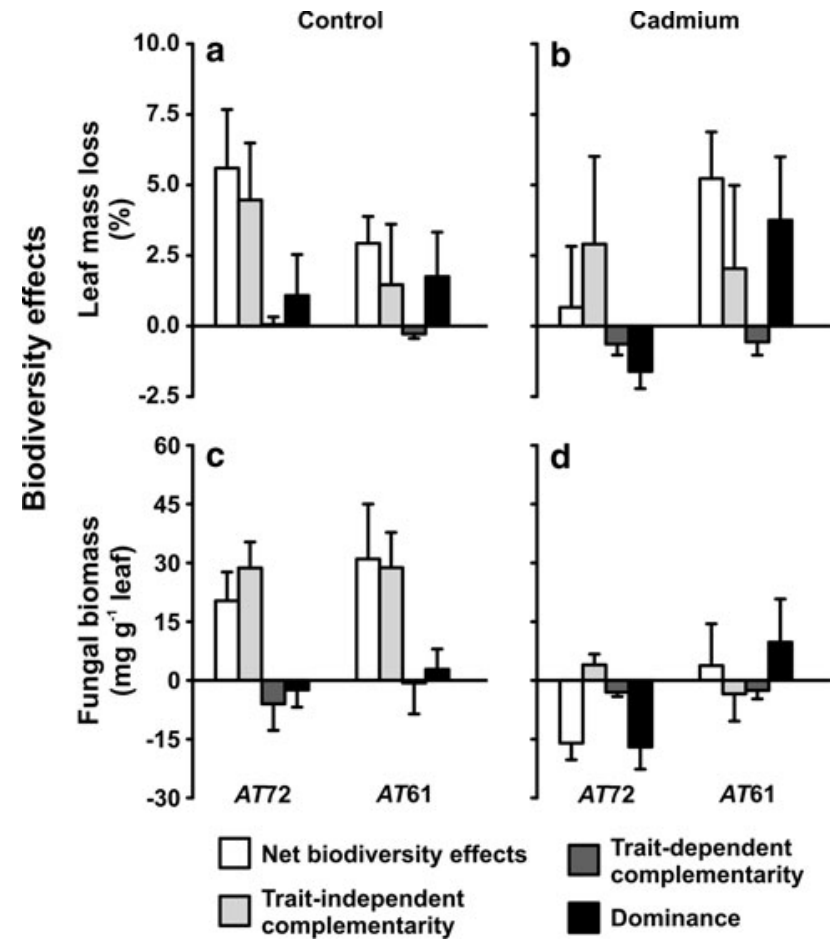

Fig. 3 Mechanisms contributing to the net biodiversity effects on a, b leaf mass loss and c, d fungal biomass in a, c control or $\mathbf{b}$, d cadmium-exposed microcosms. Data presented are average values for all multicultures containing the functional type AT72 or AT61, isolated from the unpolluted and polluted stream, respectively; the contribution of each fungal species was estimated from the relative DNA content of each fungus in multicultures (Fig. 2). Traitindependent complementarity, trait-dependent complementarity and dominance effects were estimated according to the tripartite partition model (Fox 2005). Fungal species abbreviations as in Fig. 1

significant effects) and fungal production (negative effects) for assemblages containing A. tetracladia isolated from the unpolluted site (AT72). Negative dominance effects caused this result, which can be interpreted as the most productive species in monoculture performing worse in multicultures, and suggests competitive interactions among fungal species under Cd stress. Also, assemblages with A. tetracladia from the polluted site (AT61) showed a decrease in net biodiversity effects (lack of significant effect) on biomass production, but less pronounced than those found in assemblages with $A T 72$. Interestingly, the exposure to $\mathrm{Cd}$ of assemblages containing $A$. tetracladia from the metalpolluted site (AT61) led to positive net biodiversity effects on leaf decomposition. This finding suggests that AT61 functional type has specific traits that confer on it not only high decomposer ability but also high tolerance to $\mathrm{Cd}$. According to the insurance hypothesis, environmental fluctuations may bring out species traits that are redundant under constant conditions; but under stress, those traits may become important helping to maintain processes even if others fail (Yachi and Loreau 1999). Even though this 
hypothesis has been proposed based on species diversity, our study provides evidence that intraspecific traits should be incorporated when examining biodiversity effects. Indeed, if only the Cd-sensitive functional type had been examined in this study, we would have failed to detect positive net biodiversity effects on leaf litter decomposition under metal stress.

Our study highlights the importance of environmental context to explain the variability of results when examining biodiversity-ecosystem functioning relationships as found previously by others (Mckie et al. 2009; Pascoal et al. 2010). Manipulating 1-4 aquatic hyphomycete species, Pascoal et al. (2010) showed that the exposure to zinc attenuated the positive effects of species richness on leaf decomposition. Also, the stress imposed by a cold perturbation on algal assemblages weakened the positive diversity-biomass relationship, because assemblages with more species had greater biomass reduction than the ones with fewer species (Zhang and Zhang 2006). In contrast, the exposure to stressors (e.g., drought, Mulder et al. 2001; abiotic stress due to geographic elevation, Callaway et al. 2002) led to an increase of positive interactions between plant species within assemblages.

We show that intraspecific traits, more than species number or identity, were important in maintaining processes under metal stress. Therefore, the incorporation of trait-based diversity measures into biodiversity and ecosystem functioning research may help to reconcile some apparent contradictory results on the functional role of biodiversity. Some studies have emphasized the positive effects of genetic diversity on ecosystem resistance to disturbance (Hughes and Stachowicz 2004) or resilience after climatic extremes (Reusch et al. 2005), and on the predictability in amphipod population survival in face of perturbations (Gamfeldt and Källström 2007). As recently reviewed by Hughes et al. (2008), genetic diversity has significant effects on different ecological processes with consequences at the population, community and ecosystem levels, being in some cases comparable in magnitude to the effects of species diversity. For microbial assemblages, it might not be imperative to conserve specific species, but rather to conserve specific metabolic pathways, which may be the result of millions of years of evolution and might be lost due to chance conditions (Falkowski et al. 2008).

In conclusion, fungal performances (biomass production and litter decomposition) were generally higher in multicultures than those expected from the weighted sum of monocultures due to complementarity between species. However, under metal stress, diversity effects on leaf decomposition decreased in assemblages containing the Cd-sensitive functional type, but were maintained in assemblages containing the Cd-resistant functional type with evidence of dominance effects. This finding means that environmental changes and the presence or absence of certain traits altered diversity effects and the underlying mechanisms (from complementarity to dominance). Although the number of species tested in this study (three species) corresponds to the maximum number of dominant species commonly found on decomposing leaves in the field (Pascoal et al. 2005b; Duarte et al. 2009; Fernandes et al. 2009a), higher diversity is generally found in streams (e.g., 8-28 species; Duarte et al. 2009). Thus, we must exercise caution when generalizing our conclusions to the real environment. Even so, our study provides a proof of concept that the presence of intraspecific traits can be more important than species richness to maintain ecosystem functioning under changing environmental conditions. Therefore, we encourage further research on the functional role of intraspecific diversity using higher number of species and functional types to mirror the complexity of assemblages and events in nature.

Acknowledgments The Portuguese Foundation for Science and Technology supported I. Fernandes (SFRH/BD/42215/2007). We are grateful to M.O. Gessner, R.O. Hall, Jr, and two anonymous reviewers for helpful comments on the manuscript.

\section{References}

Azevedo MM, Cássio F (2010) Effects of metals on growth and sporulation of aquatic fungi. Drug Chem Toxicol 33:269-278. doi:10.3109/01480540903431440

Balvanera P, Pfisterer AB, Buchmann N, He J-S, Nakashizuka T, Raffaelli D, Schmid B (2006) Quantifying the evidence for biodiversity effects on ecosystem functioning and services. Ecol Lett 9:1146-1156. doi:10.1111/j.1461-0248.2006.00963.x

Bärlocher F (2005) Freshwater fungal communities. In: Dighton J, Oudemans P, White J (eds) The fungal community, 3rd edn. CRC Press, Boca Raton

Bärlocher F, Corkum M (2003) Nutrient enrichment overwhelms diversity effects in leaf decomposition by stream fungi. Oikos 101:247-252. doi:10.1034/j.1600-0706.2003.12372.x

Bärlocher F, Graça MAS (2002) Exotic riparian vegetation lowers fungal diversity but not leaf decomposition in Portuguese streams. Freshwater Biol 47:1123-1135. doi:10.1046/j.13652427.2002.00836.x

Bermingham S, Maltby L, Dewey FM (1996) Monoclonal antibodies as tools to quantify mycelium of aquatic hyphomycetes. New Phytol 132:593-601. doi:10.1111/j.1469-8137.1996.tb01878.x

Callaway RM, Brooker RW, Choler P, Kikvidze Z, Lortiek CJ, Michalet R, Paolini L, Pugnaire FI, Newingham B, Aschehoug ET, Armas C, Kikodze D, Cook BJ (2002) Positive interactions among alpine plants increase with stress. Nature 417:844-848. doi:10.1038/nature00812

Cardinale BJ, Srivastava DS, Duffy JE, Wright JP, Downing AL, Sankaran M, Jouseau C (2006) Effects of biodiversity on the functioning of trophic groups and ecosystems. Nature 443:989992. doi: $10.1038 /$ nature 05202

Dang CK, Chauvet E, Gessner MO (2005) Magnitude and variability of process rates in fungal diversity-litter decomposition 
relationships. Ecol Lett 8:1129-1137. doi:10.1111/j.1461-0248. 2005.00815.x

Das M, Royer TV, Leff LG (2007) Diversity of fungi, bacteria, and actinomycetes on leaves decomposing in a stream. Appl Environ Microbiol 73:756-767. doi:10.1128/AEM.01170-06

Duarte S, Pascoal C, Cássio F, Bärlocher F (2006) Aquatic hyphomycete diversity and identity affect leaf litter decomposition in microcosms. Oecologia 147:658-666. doi:10.1007/ s00442-005-0300-4

Duarte S, Pascoal C, Garabétian F, Cássio F, Charcosset J-Y (2009) Microbial decomposer communities are mainly structured by trophic status in circumneutral and alkaline streams. Appl Environ Microbiol 79:6211-6221. doi:10.1128/AEM.00971-09

Ducklow H (2008) Microbial services: challenges for microbial ecologists in a changing world. Aquat Microb Ecol 53:13-19. doi: $10.3354 / \mathrm{ame} 01220$

Falkowski PG, Fenchel T, Delong EF (2008) The microbial engines that drive Earth's biogeochemical cycles. Science 320:10341039. doi:10.1126/science. 1153213

Fernandes I, Duarte S, Cássio F, Pascoal C (2009a) Mixtures of zinc and phosphate affect leaf litter decomposition by aquatic fungi in streams. Sci Total Environ 407:4283-4288. doi:10.1016/j. scitotenv.2009.04.007

Fernandes I, Uzun B, Pascoal C, Cássio F (2009b) Responses of aquatic fungal communities on leaf litter to temperature-change events. Int Rev Hydrobiol 94:410-418. doi:10.1002/iroh.2008 11163

Ferreira V, Gulis V, Graça MAS (2006) Whole-stream nitrate addition affects litter decomposition and associated fungi but not invertebrates. Oecologia 149:718-729. doi:10.1007/s00442006-0478-0

Fox JW (2005) Interpreting the 'selection effect' of biodiversity on ecosystem function. Ecol Lett 8:846-856. doi:10.1111/j.14610248.2005.00795.x

Gamfeldt L, Hillebrand H (2008) Biodiversity effects on aquatic ecosystem functioning - maturation of a new paradigm. Int Rev Hydrobiol 93:550-564. doi:10.1002/iroh.200711022

Gamfeldt L, Källström B (2007) Increasing intraspecific diversity increases predictability in population survival in the face of perturbations. Oikos 116:700-705. doi:10.1111/j.0030-1299. 2007.15382.x

Gessner MO (2005) Ergosterol as a measure of fungal biomass. In: Graça MAS, Bärlocher F, Gessner MO (eds) Methods to study litter decomposition: a practical guide. Springer, Dordrecht, pp 189-196

Hector A, Bell T, Connolly J, Finn J, Fox J, Kirwan L, Loreau M, McLaren J, Schmid B, Weigelt A (2009) The analysis of biodiversity experiments: from pattern toward mechanism. In: Naeem S, Bunker DE, Hector A, Loreau M, Perrings C (eds) Biodiversity, ecosystem functioning, and human wellbeing. An ecological and economic perspective. Oxford University Press, New York, pp 94-104

Hooper DU, Chapin FS III, Ewel JJ, Hector A, Inchausti P, Lavorel S, Lawton JH, Lodge DM, Loreau M, Naeem S, Schmid B, Setälä H, Symstad AJ, Vandermeer J, Wardle DA (2005) Effects of biodiversity on ecosystem functioning: a consensus of current knowledge. Ecol Monogr 75:3-35. doi:10.1890/04-0922

Hughes AR, Stachowicz JJ (2004) Genetic diversity enhances the resistance of a seagrass ecosystem to disturbance. Proc Natl Acad Sci USA 101:8998-9002. doi:10.1073/pnas.0402642101

Hughes AR, Inouye BD, Johnson MTJ, Underwood N, Vellend M (2008) Ecological consequences of genetic diversity. Ecol Lett 11:609-623. doi:10.1111/j.1461-0248.2008.01179.x

Jessup CM, Kassen R, Forde SE, Kerr B, Buckling A, Rainey PB, Bohannan BJM (2004) Big questions, small worlds: microbial model systems in ecology. Trends Ecol Evol 19:189-197. doi: $10.1016 /$ j.tree.2004.01.008

Kanagawa T (2003) Bias and artifacts in multitemplate polymerase chain reactions (PCR). J Biosci Bioeng 96:317-323. doi: 10.1016/S1389-1723(03)90130-7

Kennedy PG, Bergemann SE, Hortal S, Bruns TD (2007) Determining the outcome of field-based competition between two Rhizopogon species using real-time PCR. Mol Ecol 16:881-890. doi: 10.1111/j.1365-294X.2006.03191.x

Kominoski JS, Hoellein TJ, Kelly JJ, Pringle CM (2009) Does mixing litter of different qualities alter stream microbial diversity and functioning on individual litter species? Oikos 118:457-463. doi: 10.1111/j.1600-0706.2008.17222.x

Kubista M, Andrade JM, Bengtsson M, Forootan A, Jonák J, Lind K, Sindelka R, Sjöback R, Sjögreen B, Strömbom L, Ståhlberg A, Zoric N (2006) The real-time polymerase chain reaction. Mol Asp Med 27:95-125. doi:10.1016/j.mam.2005.12.007

Lecerf A, Dobson M, Dang CK, Chauvet E (2005) Riparian plant species loss alters trophic dynamics in detritus-based ecosystems. Oecologia 146:432-442. doi:10.1007/s00442-0050212-3

Loreau M, Hector A (2001) Partitioning selection and complementarity in biodiversity experiments. Nature 412:72-76. doi: 10.1038/35083573

Marks JC, Haden GA, Harrop BL, Reese EG, Keams JL, Watwood ME, Whitham TG (2009) Genetic and environmental controls of microbial communities on leaf litter in streams. Freshwater Biol 54:2616-2627. doi:10.1111/j.1365-2427.2009.02270.x

McKie BG, Schindler M, Gessner MO, Malmqvist B (2009) Placing biodiversity and ecosystem functioning in context: environmental perturbations and the effects of species richness in a stream field experiment. Oecologia 160:757-770. doi:10.1007/s00442009-1336-7

Mulder CPH, Uliassi DD, Doak DF (2001) Physical stress and diversity-productivity relationships: the role of positive interactions. Proc Natl Acad Sci USA 98:6704-6708. doi:10.1073/pnas. 111055298

Pascoal C, Cássio F (2004) Contribution of fungi and bacteria to leaf litter decomposition in a polluted river. Appl Environ Microbiol 70:5266-5273. doi:10.1128/AEM.70.9.5266-5273.2004

Pascoal C, Cássio F (2008) Linking fungal diversity to the functioning of freshwater ecosystems. In: Sridhar KR, Bärlocher F, Hyde KD (eds) Novel techniques and ideas in mycology. Fungal Diversity Research Series, Fungal Diversity Press, Hong Kong, pp 1-15

Pascoal C, Cássio F, Marvanová L (2005a) Anthropogenic stress may affect aquatic hyphomycete diversity more than leaf decomposition in a low-order stream. Arch Hydrobiol 162:481-496. doi: 10.1127/0003-9136/2005/0162-0481

Pascoal C, Marvanová L, Cássio F (2005b) Aquatic hyphomycete diversity in streams of Northwest Portugal. Fungal Divers 19:109-128

Pascoal C, Cássio F, Nikolcheva L, Bärlocher F (2010) Realized fungal diversity increases functional stability of leaf litter decomposition under zinc stress. Microb Ecol 59:84-93. doi: 10.1007/s00248-009-9567-z

Raviraja NS, Sridhar KR, Bärlocher F (1998) Breakdown of Ficus and Eucalyptus leaves in an organically polluted river in India: fungal diversity and ecological functions. Freshwater Biol 39:537-545. doi:10.1046/j.1365-2427.1998.00303.x

Raviraja NS, Nikolcheva LG, Bärlocher F (2006) Fungal growth and leaf decomposition are affected by amount and type of inoculum and by external nutrients. Sydowia 58:91-104

Reiss J, Bridle JR, Montoya JM, Woodward G (2009) Emerging horizons in biodiversity and ecosystem functioning research. Trends Ecol Evol 24:505-514. doi:10.1016/j.tree.2009.03.018 
Reiss J, Forster J, Cássio F, Pascoal C, Stewart R, Hirst AG (2010) When microscopic organisms inform general ecological theory. Adv Ecol Res 43:45-85. doi:10.1016/B978-0-12-385005-8.00002-2

Reusch TBH, Ehlers A, Hämmerli A, Worm B (2005) Ecosystem recovery after climatic extremes enhanced by genotypic diversity. Proc Natl Acad Sci USA 102:2826-2831. doi:10.1073/ pnas.0500008102

Soares HMVM, Boaventura RAR, Machado AASC, Esteves da Silva JCG (1999) Sediments as monitors of heavy metal contamination in the Ave river basin (Portugal): multivariate analysis of data. Environ Pollut 105:311-323. doi:10.1016/S0269-7491(99)00048-2

Sridhar KR, Krauss G, Bärlocher F, Wennrich R, Krauss G-J (2000) Fungal diversity in heavy metal polluted waters in Central Germany. Fungal Divers 5:119-129

Sridhar KR, Krauss G, Bärlocher F, Raviraja NS, Wennrich R, Baumbach R, Krauss G-J (2001) Decompostion of alder leaves in two heavy metal-polluted streams in central Germany. Aquat Microb Ecol 26:73-80. doi:10.3354/ame026073

Suberkropp K, Arsuffi TL, Anderson JP (1983) Comparison of degradative ability, enzymatic activity, and palatability of aquatic hyphomycetes grown on leaf litter. Appl Environ Microbiol 46:237-244

Treton C, Chauvet E, Charcosset J-Y (2004) Competitive interaction between two aquatic hyphomycete species and increase in leaf litter breakdown. Microb Ecol 48:439-446. doi:10.1007/s00248-0030195-8

White TJ, Bruns T, Lee S, Taylor JW (1990) Amplification and direct sequencing of fungal ribosomal RNA genes for phylogenetics. In: Innis MA, Gelfand DH, Sninsky JJ, White TJ (eds) PCR Protocols: a guide to methods and applications. Academic, New York, pp 315-322

Yachi S, Loreau M (1999) Biodiversity and ecosystem productivity in a fluctuating environment: the insurance hypothesis. Proc Natl Acad Sci USA 96:1463-1468

Zar JH (1996) Biostatistical analysis, 3rd edn. Englewood Cliffs, Prentice-Hall

Zhang Q-G, Zhang D-Y (2006) Species richness destabilizes ecosystem functioning in experimental aquatic microcosms. Oikos 112:218-226. doi:10.1111/j.0030-1299.2006.14220.x 